\title{
Short communication: Effects of level of rumen-degradable protein and corn distillers grains in corn silage-based diets on milk production and ruminal fermentation in lactating dairy cows ${ }^{1}$
}

\author{
G. I. Zanton, ${ }^{2}$ A. J. Heinrichs, ${ }^{3}$ and C. M. Jones \\ Department of Dairy and Animal Science, The Pennsylvania State University, University Park 16802
}

\begin{abstract}
Two of the potential obstacles precluding inclusion of higher levels of dry distillers grains with solubles (DDGS) in corn-based dairy cow diets are the low levels of rumen-degradable protein (RDP) and the fatty acid content and composition of DDGS. Therefore, the objective of this experiment was to evaluate the production and rumen responses to dietary alterations in the level of RDP and DDGS for dairy cows fed a high corn silage diet. The experimental design was a replicated $4 \times 4$ Latin square with 21 -d periods: $14 \mathrm{~d}$ of adaptation and $7 \mathrm{~d}$ of sampling; 16 uncannulated cows and 4 ruminally cannulated cows were blocked and assigned randomly to treatment sequences. Rations were provided as total mixed rations and were formulated to be high or low in RDP, with or without DDGS replacing soybean-based concentrates: high RDP, no DDGS (HRDP0); low RDP, no DDGS (LRDP0); low RDP, 10\% DDGS; and low RDP, 20\% DDGS. Body weight $(696 \mathrm{~kg})$ and dry matter intake $(26.6 \mathrm{~kg} / \mathrm{d})$ were not affected by treatment. Rumen ammonia concentration was greater for HRDP0 than LRDP0, but was unaffected by level of DDGS inclusion. The mean and minimum rumen $\mathrm{pH}$ and time $\mathrm{pH}$ was $<5.5$ were not different between diets. Milk production tended to be lower for cows fed HRDP0 than LRDP0 and tended to be linearly reduced as DDGS inclusion increased. Milk protein yield tended to be greater for cows fed LRDP0 than HRDP0, but was unaffected by DDGS level. Milk fat production, concentration, and fat-corrected milk were linearly reduced by increasing levels of DDGS. Based on these results, feeding DDGS at $20 \%$ of diet dry matter is not recommended for diets based on high corn silage.
\end{abstract}

\footnotetext{
Received August 3, 2012.

Accepted April 2, 2013.

${ }^{1}$ This research was a component of NC-1042: Management Systems to Improve the Economic and Environmental Sustainability of Dairy Enterprises.

${ }^{2}$ Present address: Novus International Inc., 20 Research Park Drive, St. Charles, MO 63304.

${ }^{3}$ Corresponding author: ajh@psu.edu
}

Key words: dry distillers grains with solubles, rumendegradable protein, corn silage

\section{Short Communication}

Distillers grains are a by-product of fuel-ethanol production with relatively high levels of $\mathrm{CP}$ and RUP (Kleinschmit et al., 2007a). Distillers grains have been studied as a protein source for ruminant animals in the past, and research has generally indicated that this source of feed compares favorably with other protein sources, both for lactating dairy cattle as well as for growing ruminants (Firkins et al., 1985; Schingoethe et al., 1999; Kleinschmit et al., 2006). These properties confer distillers grains with the potential to provide a substantial amount of AA postruminally. Two of the major obstacles precluding high inclusion of distillers in the diet of dairy cows are the high level of RUP and imbalance of AA relative to the requirements of milk protein secretion. Although the higher RUP in distillers does make it an attractive feedstuff to allow AA to bypass rumen fermentation, feeding too much RUP at the expense of RDP can limit microbial protein synthesis (Ipharraguerre and Clark, 2005).

When diets for dairy cows contained corn silage as the only forage, milk yield was depressed at the highest level of dry distillers grains with solubles (DDGS; 36\% DM; Owen and Larson, 1991), but not the lowest level used in that experiment (18\% DM). When alfalfa hay or silage is fed, however, milk production has been unaffected (18 to $30 \%$ distillers grains; Schingoethe et al., 1999; Liu et al., 2000) or enhanced (10 to 20\% distillers grains; Nichols et al., 1998; Anderson et al., 2006; Kleinschmit et al., 2006) by additional levels of DDGS or wet distillers grains compared with control protein supplement. Given the AA composition of soy-based and corn-based rumen bypass proteins, the potential limitation of microbial protein synthesis, and the potential influence of the forage component of the diet, the objective of this experiment was to evaluate the production and rumen responses to dietary alterations in the level of RDP and DDGS for dairy cows fed a high-corn silage diet. 
Table 1. Ingredient composition of diets fed with high (HRDP) or low (LRDP) RDP and increasing levels of dried distillers grains with solubles (DDGS)

\begin{tabular}{|c|c|c|c|c|}
\hline \multirow[b]{2}{*}{ Item } & \multirow{2}{*}{$\frac{\text { HRDP }}{0 \% \text { DDGS }}$} & \multicolumn{3}{|c|}{ LRDP } \\
\hline & & $0 \%$ DDGS & $10 \%$ DDGS & $20 \%$ DDGS \\
\hline \multicolumn{5}{|l|}{ Ingredient, $\%$ of DM } \\
\hline Corn silage $^{1}$ & 47.00 & 47.00 & 47.00 & 47.00 \\
\hline Grass hay ${ }^{2}$ & 3.00 & 3.00 & 3.00 & 3.00 \\
\hline DDGS $^{3}$ & 0.00 & 0.00 & 10.00 & 20.00 \\
\hline Ground corn & 15.33 & 16.40 & 14.20 & 12.00 \\
\hline Soy Choice ${ }^{4}$ & 4.00 & 4.00 & 4.00 & 4.00 \\
\hline Canola meal & 7.50 & 7.50 & 7.50 & 7.50 \\
\hline Soybean meal (48\%) & 3.45 & 0.00 & 0.00 & 0.00 \\
\hline Soy Pass 5 & 0.00 & 4.15 & 2.08 & 0.00 \\
\hline Soybean hulls & 6.00 & 4.75 & 2.38 & 0.00 \\
\hline Roasted soybeans & 6.40 & 5.82 & 2.91 & 0.00 \\
\hline Cottonseed hulls & 2.00 & 2.00 & 2.00 & 2.00 \\
\hline Alifet $^{6}$ & 0.82 & 0.88 & 0.44 & 0.00 \\
\hline Urea & 0.50 & 0.50 & 0.50 & 0.50 \\
\hline Mineral $\operatorname{mix}^{7}$ & 4.00 & 4.00 & 4.00 & 4.00 \\
\hline \multicolumn{5}{|c|}{ Composition, $\%$ of DM or as indicated } \\
\hline $\mathrm{CP}$ & 17.6 & 17.5 & 17.5 & 17.6 \\
\hline $\mathrm{RDP}^{8}$ & 10.5 & 9.6 & 9.8 & 9.9 \\
\hline RUP $^{8}$ & 7.1 & 7.9 & 7.7 & 7.7 \\
\hline MP supplied,$^{8} \mathrm{~g} / \mathrm{d}$ & 3,093 & 3,291 & 3,185 & 3,187 \\
\hline RDP supplied, ${ }^{8} \mathrm{~g} / \mathrm{d}$ & 2,784 & 2,588 & 2,584 & 2,647 \\
\hline RUP supplied, $8 / \mathrm{d}$ & 1,886 & 2,119 & 2,035 & 2,041 \\
\hline Lys, ${ }^{8} \% \mathrm{MP}$ & 6.22 & 6.05 & 5.86 & 5.63 \\
\hline Met, $8 \mathrm{MP}$ & 1.77 & 1.72 & 1.77 & 1.82 \\
\hline Lys:Met & 3.51 & 3.51 & 3.31 & 3.09 \\
\hline Ether extract & 5.4 & 5.4 & 5.4 & 5.4 \\
\hline NDF & 32.3 & 32.7 & 33.5 & 34.4 \\
\hline $\mathrm{ADF}$ & 19.8 & 19.2 & 19.5 & 19.8 \\
\hline $\mathrm{NE}_{\mathrm{L}}, \mathrm{Mcal} / \mathrm{kg}$ & 1.60 & 1.59 & 1.60 & 1.59 \\
\hline NFC & 41.3 & 42 & 40.6 & 39.3 \\
\hline
\end{tabular}

${ }^{1}$ Corn silage contained (\% of DM) $38.1 \%$ NDF, $8.1 \%$ CP, and $48.4 \%$ NFC.

${ }^{2}$ Grass hay contained (\% of DM) $70.1 \%$ NDF and $7.5 \%$ CP.

${ }^{3}$ Dried distillers grains with solubles contained (\% of DM) $28.7 \%$ CP, $33.0 \%$ NDF, $4.3 \%$ neutral detergentinsoluble CP, and $11.9 \%$ ether extract.

${ }^{4}$ Soy Choice (expeller soybean meal from Wenger's Feed Mill Inc., Rheems, PA) contained (\% of DM) 47.7\% $\mathrm{CP}, 16.3 \% \mathrm{NDF}$, and $27.5 \% \mathrm{NFC}$.

${ }^{5}$ Soy Pass is nonenzymatic browned, solvent-extracted soybean meal (Borregaard LignoTech USA Inc., Rothschild, WI).

${ }^{6}$ Alifet (Alifet USA Inc., Cincinnati, OH) is hydrogenated tallow mixed with wheat starch and crystallized (92\% fat).

${ }^{7}$ The premix contained (\%, as-is basis) trace mineral mix, 0.88; $\mathrm{MgO}(54 \% \mathrm{Mg}), 8.3 ; \mathrm{NaCl}, 6.4$; vitamin $\mathrm{ADE}$ premix, 1.73; limestone, 35.8; selenium premix, 1.09; and corn DDGS, 45.8. Composition: Ca, 14.1\%; P, 0.35\%; $\mathrm{Mg}, 4.58 \%$; K, 0.41\%; S, 0.31\%; Mn, 1,071 mg/kg; Cu, $358 \mathrm{mg} / \mathrm{kg} ; \mathrm{Zn}, 1,085 \mathrm{mg} / \mathrm{kg} ; \mathrm{Fe}, 181 \mathrm{mg} / \mathrm{kg} ; \mathrm{Se}, 6.67$ $\mathrm{mg} / \mathrm{kg}$; Co, $5.4 \mathrm{mg} / \mathrm{kg}$; I, $13.4 \mathrm{mg} / \mathrm{kg}$; vitamin A, 262,101 IU/kg; vitamin D, 65,421 IU/kg; and vitamin E, $1,971 \mathrm{IU} / \mathrm{kg}$.

${ }^{8}$ Composition based on chemical composition of feedstuffs and as predicted by NRC (2001), based on actual milk production, BW, milk composition, and intakes.

The experimental design was a replicated, $4 \times 4$ Latin square with 21-d periods: $14 \mathrm{~d}$ of adaptation and $7 \mathrm{~d}$ of sampling; 20 cows were used for the study, with 5 total cows and 1 ruminally cannulated cow per treatment; cows were blocked and assigned randomly to treatment sequences. Diets (Table 1) were fed once daily at $0800 \mathrm{~h}$ for a $5 \%$ refusal rate, and water was offered ad libitum. Diets consisted of increasing levels of DDGS that replaced soybean meal or soy-based ingredients [high RDP, no DDGS (HRDP0); low RDP, no DDGS (LRDP0); low RDP, 10\% DDGS; and low RDP, $20 \%$ DDGS]. This strategy was used to vary the level of RDP and RUP across treatments while keeping energy and protein similar across diets. Feedstuffs and TMR samples were collected daily and composited every $15 \mathrm{~d}$ and monthly, respectively; concentrate samples were collected once per week. Immediately after collection, samples were dried in a forced-air oven $\left(55^{\circ} \mathrm{C}\right)$ for 3 consecutive $\mathrm{d}$ and then stored for further analyses. Feedstuffs and TMR were ground through a 


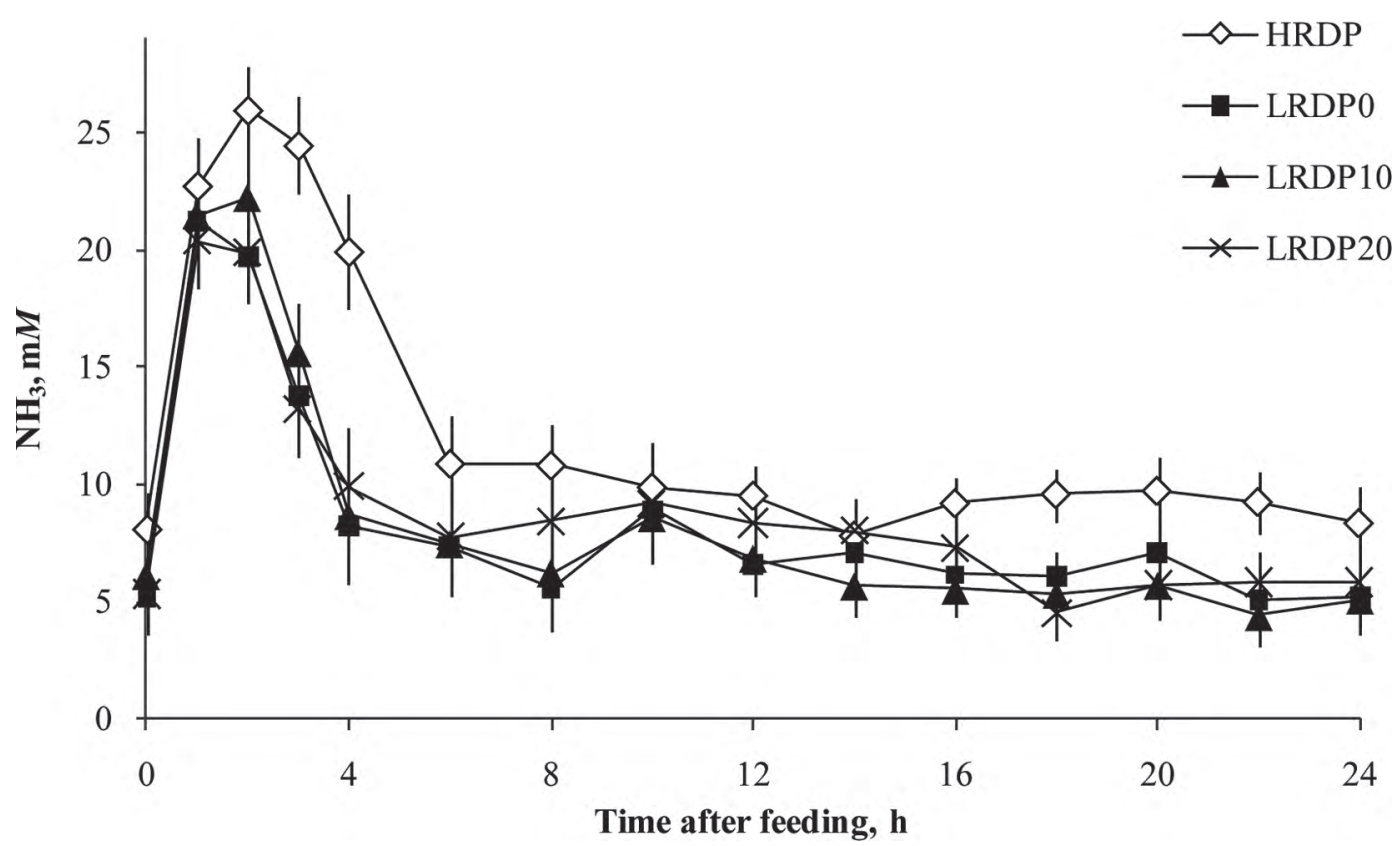

Figure 1. Rumen $\mathrm{NH}_{3}$ levels of cows fed high or low levels of RDP with 0, 10, or $20 \%$ added dried distillers grains with solubles (DDGS). HRDP $=$ high RDP; LRDP0 = low RDP and 0\% DDGS; LRDP10 = low RDP and 10\% DDGS; LRDP20 = low RDP and $20 \%$ DDGS. Error bars indicate SE.

1-mm screen using a Wiley Mill (Arthur H. Thomas Co., Philadelphia, PA) and analyzed for DM, OM, ash (AOAC International, 2005), ether extract (AOAC International, 2005), and ADF and NDF (Van Soest et al., 1991) using an Ankom ${ }^{200}$ Fiber Analyzer (Ankom Technology Corp., Fairport, NY) with heat-stable $\alpha$-amylase and sodium sulfite for the NDF procedure. Crude protein was analyzed using the Kjeldahl method (AOAC International, 2005) and soluble protein by the methods of Krishnamoorthy et al. (1983). Diet RUP was calculated from NRC guidelines (NRC, 2001).
Samples of all ingredients were composited by period and individual forages and a representative mixture of concentrate feeds were analyzed for nutrient composition by wet chemistry procedures (Cumberland Valley Analytical Services Inc., Maugansville, MD). Milking occurred twice daily at 0500 and $1700 \mathrm{~h}$ in a double-10 herringbone milking parlor equipped with the AfiFarm system (S.A.E. Afikim, Kibbutz Afikim, Israel; US distributor: Germania Dairy Automation, Waunakee, WI). Milk yield for individual cows was recorded at each milking and animals were weighed daily upon exit-

Table 2. Production responses in cows fed diets with high (HRDP) or low (LRDP) RDP and increasing levels of dried distillers grains with solubles (DDGS; $\mathrm{n}=20$ cows)

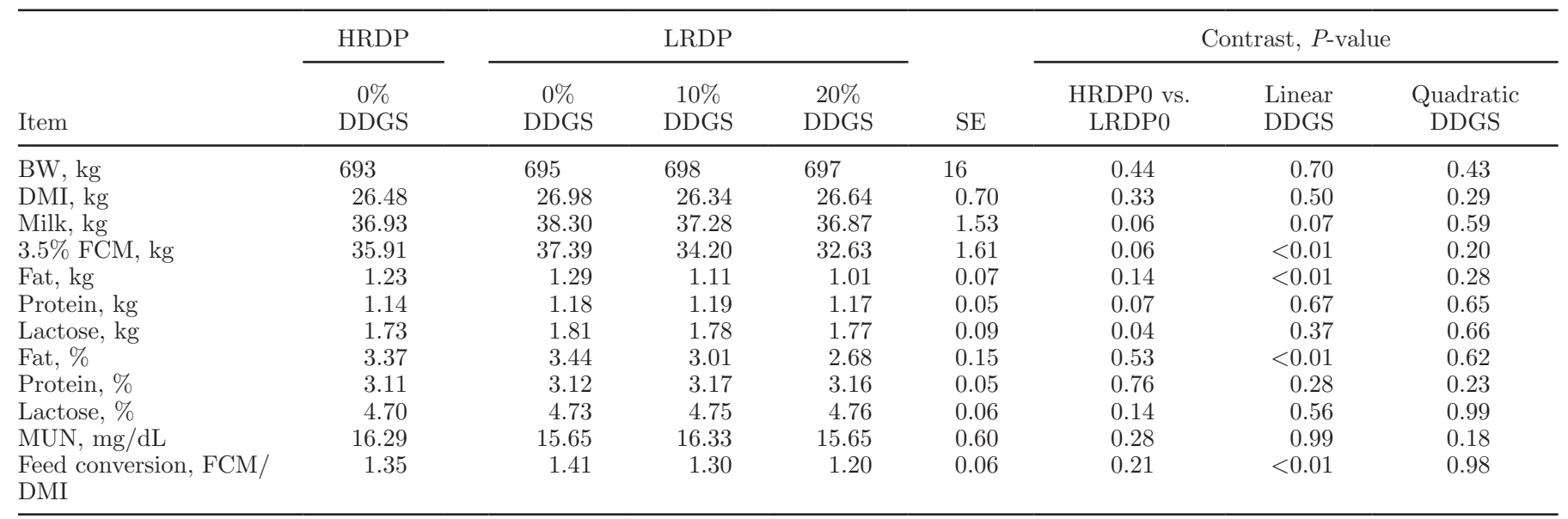


Table 3. Rumen fermentation characteristics in cows fed diets with high (HRDP) or low (LRDP) RDP and increasing levels of dried distillers grains with solubles (DDGS; $\mathrm{n}=4$ cannulated cows)

\begin{tabular}{|c|c|c|c|c|c|c|c|c|}
\hline \multirow[b]{2}{*}{ Item } & \multirow{2}{*}{$\begin{array}{c}\text { HRDP } \\
0 \% \\
\text { DDGS }\end{array}$} & \multicolumn{3}{|c|}{ LRDP } & \multirow[b]{2}{*}{$\mathrm{SE}$} & \multicolumn{3}{|c|}{ Contrasts } \\
\hline & & $\begin{array}{c}0 \% \\
\text { DDGS }\end{array}$ & $\begin{array}{c}10 \% \\
\text { DDGS }\end{array}$ & $\begin{array}{c}20 \% \\
\text { DDGS }\end{array}$ & & $\begin{array}{l}\text { HRDP0 vs. } \\
\text { LRDP0 }\end{array}$ & $\begin{array}{l}\text { Linear } \\
\text { DDGS }\end{array}$ & $\begin{array}{c}\text { Quadratic } \\
\text { DDGS }\end{array}$ \\
\hline Average $\mathrm{pH}$ & 5.81 & 5.88 & 5.86 & 5.86 & 0.11 & 0.59 & 0.92 & 0.90 \\
\hline Minimum pH & 5.10 & 5.04 & 5.13 & 5.08 & 0.09 & 0.36 & 0.54 & 0.18 \\
\hline Time $\mathrm{pH}<5.5, \mathrm{~h}$ & 9.47 & 7.45 & 9.80 & 9.82 & 2.13 & 0.29 & 0.22 & 0.47 \\
\hline $\mathrm{NH}_{3}, \mathrm{~m} M$ & 12.04 & 8.12 & 8.02 & 8.63 & 1.21 & $<0.01$ & 0.63 & 0.70 \\
\hline
\end{tabular}

ing the parlor. Milk fat and protein were sampled and analyzed from 2 consecutive milkings every month at d 19 and 20 of each period and analyzed (Dairy One, Ithaca, NY). Rumen fluid was collected for analysis of $\mathrm{pH}$ and $\mathrm{NH}_{3}$ for $24 \mathrm{~h}$ over d 17 and 18, and rumen contents were evacuated on d 16 and 20 for estimation of pool sizes. Rumen contents were sampled on d 18 to 19 at $-2,-1,0,1,2,4,6,8,10,12,18$, and 24 $\mathrm{h}$ after the $0800 \mathrm{~h}$ feeding. Rumen fluid was strained through 4 layers of cheesecloth, $\mathrm{pH}$ was recorded (model M90 pH meter; Corning Inc., Corning, NY), and 15 $\mathrm{mL}$ was placed into bottles containing $3 \mathrm{~mL}$ of $25 \%$ metaphosphoric acid and $3 \mathrm{~mL}$ of $0.6 \%$ 2-ethyl butyric acid (internal standard). Samples were stored at $-20^{\circ} \mathrm{C}$ until $\mathrm{NH}_{3}$ analysis was conducted. Later, samples were centrifuged 3 times at $4,000 \times g$ for $30 \mathrm{~min}$ at $4^{\circ} \mathrm{C}$ to obtain clear supernatant, which was analyzed for rumen $\mathrm{NH}_{3}$ according to Moody et al. (2007). Due to unequally spaced rumen sampling, mean $\mathrm{pH}$ and $\mathrm{NH}_{3}$ concentrations were determined by calculating the area under the response curve according to the trapezoidal rule (Moody et al., 2007).

All data were analyzed using PROC Mixed of SAS (version 9.1; SAS Institute Inc., Cary, NC), with period and treatment as fixed effects and cow as a random effect. Contrasts of interest were HRDP0 versus LRDP0 and linear and quadratic effects of level of DDGS, with differences declared at $P<0.05$. Rumen $\mathrm{pH}$ and $\mathrm{NH}_{3}$ were analyzed as repeated measures, with time of sampling as the repeated term and cow nested within period as the subject.

Body weight $(696 \mathrm{~kg})$ and DMI $(26.6 \mathrm{~kg} / \mathrm{d})$ were not affected by treatment for diets containing 0,10 , or $20 \%$ DDGS (Table 2). Milk fat ( $\mathrm{kg}$ and \%) and 3.5\% FCM linearly decreased with increasing levels of DDGS, and a trend was observed for lower milk yield $(\mathrm{kg})$ with increasing levels of DDGS $(P=0.07)$. In addition, a significant decrease in feed conversion (FCM/DMI) was noted as higher levels of DDGS were added to the diet. Although several reports have shown that DDGS can be included at up to $20 \%$ of diet DM without limiting milk yield or milk fat production (Schingoethe et al., 2009), others have suggested that in corn silage-based diets (Kleinschmit et al., 2007b) milk yield and fat production can be negatively affected, as was shown in the current experiment. Lactose production was greater, and a trend was observed for milk, protein, and FCM production to be increased for LRDP compared with HRDP. Mean and minimum rumen $\mathrm{pH}$ and time $\mathrm{pH}$ was $<5.5$ were not affected by DDGS level $(P>0.25$; Table 3), which is similar to previous results (Kelzer et al., 2009; Zhang et al., 2010). Rumen $\mathrm{NH}_{3}$ concentration was greater for HRDP0 than LRDP0 $(P<0.01)$, as expected, but was unaffected by level of DDGS inclusion up to the 20\% that was studied (Figure 1). Previous studies also reported no effect on rumen $\mathrm{NH}_{3}$ for cows fed distillers grains diets (Kelzer et al., 2009; Zhang et al., 2010).

Soybean meal is the typical feed against which other protein sources are evaluated. In the present experiment, DDGS were compared with soy protein-based diets including soybean meal for the HRDP diet. To balance the major chemical constituents, a blend of protein and fat sources were exchanged for DDGS. No indications existed that exchanging DDGS for soy protein sources within these high corn silage diets resulted in protein-dependent productive changes. However, as it relates to the significant findings of this experiment, the fat from DDGS replaced fat from a blend of soy and hydrogenated tallow. Considering the FA composition of DDGS and the $\mathrm{pH}$ realized in this experiment, it is probable that altered biohydrogenation was occurring to reduce de novo FA synthesis (Bauman and Griinari, 2003), although this was not measured in the current experiment. It should be noted, however, that differences in FA content between diets due to differing ingredients may have contributed to the observed results.

Based on these results, replacing a blend of ingredients with DDGS at $20 \%$ of diet DM is not recommended for diets based on high corn silage due to significant reductions that are observed in milk fat production and the tendency for reductions in milk yield. 


\section{ACKNOWLEDGMENTS}

This study was funded by the Pennsylvania Department of Agriculture (Harrisburg).

\section{REFERENCES}

Anderson, J. L., D. J. Schingoethe, K. F. Kalscheur, and A. R. Hippen. 2006. Evaluation of dried and wet distillers grains included at two concentrations in the diets of lactating dairy cows. J. Dairy Sci. 89:3133-3142.

AOAC International. 2005. Official Methods of Analysis. 18th ed. AOAC International, Arlington, VA.

Bauman, D. E., and J. M. Griinari. 2003. Nutritional regulation of milk fat synthesis. Annu. Rev. Nutr. 23:203-227.

Firkins, J. L., L. L. Berger, and G. C. Fahey, Jr. 1985. Evaluation of wet and dry distillers grains and wet and dry corn gluten feeds for ruminants. J. Anim. Sci. 60:847-860.

Ipharraguerre, I. R., and J. H. Clark. 2005. Impacts of the source and amount of crude protein on the intestinal supply of nitrogen fractions and performance of dairy cows. J. Dairy Sci. 88(Suppl. 1):E22-E37.

Kelzer, J. M., P. J. Kononoff, A. M. Gehman, L. O. Tedeschi, K. Karges, and M. L. Gibson. 2009. Effects of feeding three types of corn-milling coproducts on milk production and ruminal fermentation of lactating Holstein cattle. J. Dairy Sci. 92:5120-5132.

Kleinschmit, D. H., J. L. Anderson, D. J. Schingoethe, K. F. Kalscheur, and A. R. Hippen. 2007a. Ruminal and intestinal degradability of distillers grains plus solubles varies by source. J. Dairy Sci. 90:2909-2918.

Kleinschmit, D. H., D. J. Schingoethe, A. R. Hippen, and K. F. Kalscheur. 2007b. Dried distillers grains plus solubles with corn silage or alfalfa hay as the primary forage source in dairy cow diets. J. Dairy Sci. 90:5587-5599.

Kleinschmit, D. H., D. J. Schingoethe, K. F. Kalscheur, and A. R. Hippen. 2006. Evaluation of various sources of corn dried distill- ers grains plus solubles for lactating dairy cattle. J. Dairy Sci 89:4784-4794.

Krishnamoorthy, U., C. J. Sniffen, M. D. Stern, and P. J. Van Soest. 1983. Evaluation of a mathematical-model of rumen digestion and an in vitro simulation of rumen proteolysis to estimate the rumen-undegraded nitrogen-content of feedstuffs. Br. J. Nutr. 50:555-568.

Liu, C., D. J. Schingoethe, and G. A. Stegeman. 2000. Corn distillers grains versus a blend of protein supplements with or without ruminally protected amino acids for lactating cows. J. Dairy Sci. 83:2075-2084.

Moody, M. L., G. I. Zanton, J. M. Daubert, and A. J. Heinrichs. 2007. Nutrient utilization of differing forage-to-concentrate ratios by growing Holstein heifers. J. Dairy Sci. 90:5580-5586.

Nichols, J. R., D. J. Schingoethe, H. A. Maiga, M. J. Brouk, and M. S. Piepenbrink. 1998. Evaluation of corn distillers grains and ruminally protected lysine and methionine for lactating dairy cows. J. Dairy Sci. 81:482-491.

NRC. 2001. Nutrient Requirements of Dairy Cattle. 7th rev. ed. Natl. Acad. Sci., Washington, DC.

Owen, F. G., and L. L. Larson. 1991. Corn distillers dried grains versus soybean-meal in lactation diets. J. Dairy Sci. 74:972-979.

Schingoethe, D. J., M. J. Brouk, and C. P. Birkelo. 1999. Milk production and composition from cows fed wet corn distillers grains. J Dairy Sci. 82:574-580.

Schingoethe, D. J., K. F. Kalscheur, A. R. Hippen, and A. D. Garcia. 2009. Invited review: The use of distillers products in dairy cattle diets. J. Dairy Sci. 92:5802-5813.

Van Soest, P. J., J. B. Robertson, and B. A. Lewis. 1991. Methods for dietary fiber, neutral detergent fiber, and nonstarch polysaccharides in relation to animal nutrition. J. Dairy Sci. 74:3583-3597.

Zhang, S. Z., G. B. Penner, W. Z. Yang, and M. Oba. 2010. Effects of partially replacing barley silage or barley grain with dried distillers grains with solubles on rumen fermentation and milk production of lactating dairy cows. J. Dairy Sci. 93:3231-3242. 